Note

\section{Bicyclic Phosphate Binding to Cyclodextrin: A Receptor Model}

\author{
Yoshihisa Ozoe, Kazuo MochIDA \\ and Morifusa ETo*
}

\author{
Department of Environmental Betterment, \\ Shimane University, \\ Matsue 690, Japan \\ * Department of Agricultural Chemistry, \\ Kyushu University, \\ Fukuoka 812, Japan
}

Received Jamuary 23, 1981

Bicyclic phosphates with suitable substituents (BP, 4substituted 2,6,7-trioxa-1-phosphabicyclo[2.2.2]octane 1oxide) are highly toxic convulsants whose toxicity is due to the antagonistic action against GABA synapses. ${ }^{1 \sim 3)}$ In a previous paper, ${ }^{4)}$ we reported that steric and hydrophobic interactions between the bridgehead substituents of BPs and their receptor may play an important role in the primary action of this class of convulsants. However, the receptor has not been isolated yet, and little is known about the structure and nature of the receptor.

Cyclodextrin (CD), a cyclic oligosaccharide constructed from six, seven, or eight $\alpha(1 \rightarrow 4)$-linked glucose units, has a cylindrical cavity in the molecule and includes a variety of compounds which fit into it to form inclusion complexes. ${ }^{5}$ The main driving force for the complex formation is considered to be hydrophobic and van der Waals interactions. ${ }^{6)}$

The present study was undertaken to obtain some information on the structure of the receptor from examination of interactions between BP homologs and CD, the $C D$ being used as a simple model of the receptor.

Most BPs were prepared by the reaction of the corresponding triols with phosphoryl chloride. The details of the synthetic methods and chemical properties of new compounds will be reported elsewhere.

The association constants $\left(K_{2}\right)$ for BP-CD complexes were determined by analysis of the spectrophotometrically observed inhibitory effect of $\mathrm{BP}$ on the association of $\mathrm{CD}$ with an azo dye at $25^{\circ} \mathrm{C}$. ${ }^{6}$ Methyl Orange in $0.10 \mathrm{M} \mathrm{H}_{2} \mathrm{SO}_{4}$ solution, the ionic strength $\left(I_{\mathrm{c}}\right)$ of which was adjusted to $0.50 \mathrm{M}$ with $\mathrm{Na}_{2} \mathrm{SO}_{4}$, and 4-(4-hydroxy-1-naphthylazo)-1naphthalenesulfonate in a citrate-phosphate buffer $(\mathrm{pH}$ $4.0, I_{c}=0.06 \mathrm{M}$ ) were used as azo dyes for $\alpha-\mathrm{CD}$ and $\beta-\mathrm{CD}$ systems, respectively.

The association constants of twenty BPs for $\alpha-\mathrm{CD}$ and twenty-three BPs for $\beta$-CD are listed in Table I. The binding of each BP to $\beta$-CD was approximately 10 times stronger than that to $\alpha-\mathrm{CD}$. The addition of 4-amino BP did not affect the absorbance of a Methyl Orange- $\alpha-C D$ system, i.e., the BP associates very weakly with $\alpha-\mathrm{CD}$. When regression analysis was applied to $\mathrm{BP}-\alpha-\mathrm{CD}$ systems, linear regression equations 1 and 2 were derived. (4-Acetyl, 4-phenyl, 4-nitro, and 4-amino BPs are excluded from the present analysis, since the $E_{\mathrm{s}}^{\mathrm{c}}$ values cannot be definitely estimated.) For seventeen BPs including BPs with heteroatom-substituted groups;

$$
\begin{aligned}
& \log K_{\mathrm{a}}=0.167 \pi+0.319 E_{\mathrm{s}}^{\mathrm{c}}+2.036, \\
&( \pm 0.090)( \pm 0.207) \\
& n=17, \quad r=0.762, \quad s=0.224, \quad F=9.68,
\end{aligned}
$$

and for eleven 4-alkyl BPs and 4-cyclohexyl BP;

$$
\begin{aligned}
& \log K_{\mathrm{a}}=0.339 \pi+0.370 E_{\mathrm{s}}^{\mathrm{c}}+1.712, \\
&( \pm 0.259) \quad( \pm 0.267) \\
& n=12, \quad r=0.769, \quad s=0.238, \quad F=6.52 .
\end{aligned}
$$

In the above equations $\pi$ is the hydrophobic parameter of the bridgehead substituent, given by $\pi=f_{\mathrm{X}}-f_{\mathrm{H}}\left(f_{\mathrm{X}}\right.$ is the hydrophobic fragmental constant of substituent $\mathrm{X}$ and $f_{\mathrm{H}}$ is that of hydrogen $)^{7,8)} ; E_{\mathrm{s}}{ }^{\mathrm{c}}$, Hancock's steric parameter ${ }^{9,10)} ; n$, the number of data points; $r$, the correlation coefficient; $s$, the standard deviation; $F$, the $F$ value. The figures in parentheses are the $95 \%$ confidence intervals. Equations 1 and 2 indicate that the hydrophobic interaction of the bridgehead substitutuent with $\mathrm{CD}$ is significant for the complex formation and that a sterically unfavorable interaction takes place between the branched groups and the $\alpha-C D$ cavity. The cavity $\left(4.5 \AA^{5)}\right)$ of $\alpha-C D$ may be too small to include BPs with branched substituents deeply.

When the values of $\log K_{\mathrm{a}}$ for $\beta$-CD systems were plotted against $\pi$ values, an approximately linear correlation was obtained. Only two BPs, 4-dimethoxymethyl and 4(1-hydroxyethyl) BPs, showed a large deviation from the correlation. In spite of their low hydrophobicity, the $K_{\mathrm{a}}$ values were relatively large. The omission of the above two outliers gave Eq. 3:

$$
\begin{gathered}
\log K_{\mathrm{a}}=0.068 \pi-0.189 E_{\mathrm{s}}^{\mathrm{c}}+2.415, \\
( \pm 0.068) \quad( \pm 0.135) \\
n=17, \quad r=0.826, \quad s=0.135, \quad F=15.04 .
\end{gathered}
$$

Regression equation 3 was improved considerably by the omission of BPs with heteroatom-substituted groups and 4-allyl BP as indicated in Eq. 4:

$$
\begin{aligned}
& \log K_{\mathrm{a}}=0.190 \pi-0.187 E_{\mathrm{s}}^{\mathrm{c}}+2.149, \\
&( \pm 0.129) \quad( \pm 0.134) \\
& n=12, \quad r=0.897, \quad s=0.119, \quad F=18.48 .
\end{aligned}
$$

Although the addition of the inductive substituent constant $\sigma^{* 11)}$ or $\pi^{2}$ term improved the correlation, it was concluded from the $t$-test that the terms are not significant. Contrary to the $\alpha-C D$ system, the coefficient of the $E_{\mathrm{s}}{ }^{\mathrm{c}}$ term in Eq. 4 was negative, indicating that the bulkier the substituents of BPs examined, the more stable the inclusion complexes, provided that $\pi$ is constant. The $\beta$-CD cavity $\left(\sim 7.0 \AA^{5}\right)$ may be large enough to enclose a bulky 
Table I. Substituent Constants and AsSOCIATION CONSTANTS FOR REGRESSION ANALYSIS

\begin{tabular}{|c|c|c|c|c|}
\hline \multirow{2}{*}{ Substituent } & \multirow{2}{*}{$\pi^{a}$} & \multirow{2}{*}{$E_{\mathrm{s}}^{c d}$} & \multicolumn{2}{|c|}{$\log K_{\mathrm{a}}\left(\mathrm{M}^{-1}\right)$} \\
\hline & & & $\alpha-C D$ & $\beta-\mathrm{CD}$ \\
\hline $\mathrm{CH}_{3}$ & 0.66 & 0.00 & 1.95 & 2.31 \\
\hline $\mathrm{C}_{2} \mathrm{H}_{5}$ & 1.20 & -0.38 & 2.04 & 2.44 \\
\hline $\mathrm{C}_{3} \mathrm{H}_{7}$ & 1.74 & -0.67 & 2.19 & 2.53 \\
\hline $\mathrm{CH}\left(\mathrm{CH}_{3}\right)_{2}$ & 1.61 & -1.08 & 1.71 & 2.77 \\
\hline $\mathrm{C}_{4} \mathrm{H}_{9}$ & 2.28 & -0.70 & 2.33 & 2.65 \\
\hline $\mathrm{CH}_{2} \mathrm{CH}\left(\mathrm{CH}_{3}\right)_{2}$ & $2.15^{b}$ & -1.24 & 1.63 & 2.76 \\
\hline $\mathrm{CH}\left(\mathrm{CH}_{3}\right) \mathrm{C}_{2} \mathrm{H}_{5}$ & $2.15^{b}$ & -1.74 & 1.82 & 2.79 \\
\hline $\mathrm{C}\left(\mathrm{CH}_{3}\right)_{3}$ & 1.99 & -2.46 & 1.57 & 2.98 \\
\hline $\mathrm{C}_{5} \mathrm{H}_{11}$ & 2.82 & -0.71 & 2.78 & 2.61 \\
\hline $\mathrm{C}_{2} \mathrm{H}_{4} \mathrm{CH}\left(\mathrm{CH}_{3}\right)_{2}$ & $2.69^{b}$ & -0.66 & 2.01 & 2.97 \\
\hline $\mathrm{CH}\left(\mathrm{CH}_{3}\right) \mathrm{C}_{3} \mathrm{H}_{7}$ & $2.69^{b}$ & $-1.55^{e}$ & 2.23 & 2.99 \\
\hline $\mathrm{CCOH}_{3}$ & -1.36 & $-f$ & 1.70 & 2.30 \\
\hline $\mathrm{CH}(\mathrm{OH}) \mathrm{CH}_{3}$ & $-0.92^{b}$ & $-1.19^{e}$ & 1.63 & 2.90 \\
\hline $\mathrm{OCH}_{3}$ & -1.77 & -0.05 & 1.90 & 2.38 \\
\hline $\mathrm{CH}\left(\mathrm{OCH}_{3}\right)_{2}$ & $-0.45^{c}$ & $-1.30^{e}$ & 1.52 & 3.53 \\
\hline $\mathrm{CH}_{2} \mathrm{Br}$ & 0.51 & -0.58 & 1.96 & 2.61 \\
\hline $\mathrm{CH}_{2} \mathrm{Cl}$ & 0.37 & -0.55 & & 2.63 \\
\hline $\mathrm{C}_{6} \mathrm{H}_{5}$ & 1.67 & $\ldots f$ & 1.70 & 2.62 \\
\hline $\mathrm{CH}_{2} \mathrm{OCH}_{3}$ & -0.46 & -0.50 & 1.71 & 2.58 \\
\hline$c-\mathrm{C}_{6} \mathrm{H}_{11}$ & $2.99^{b}$ & -1.40 & 2.10 & 3.10 \\
\hline $\mathrm{CH}_{2} \mathrm{CH}=\mathrm{CH}_{2}$ & 1.19 & $-1.48^{g}$ & & 2.63 \\
\hline $\mathrm{NO}_{2}$ & -1.39 & $-f$ & 1.78 & 1.87 \\
\hline $\mathrm{NH}_{2}$ & -1.77 & $-f$ & - & 2.09 \\
\hline
\end{tabular}

a Taken from ref. 8, unless otherwise noted.

$b$ Estimated from the $\pi$ value of each related substituent according to ref. 8 .

c Calcd by $\log P_{\mathrm{CH}_{2}\left(\mathrm{OCH}_{3}\right)_{2}}-\log P_{\mathrm{H}_{2}}$.

d Taken from ref. 10, unless otherwise noted.

e Caled according to Eq. 19 in ref. 10.

f. Not definitely estimated.

$g$ The $E_{\mathrm{s}}$ value for the allyl group was evaluated from that of the vinyl group (ref. 14) using Eq. 13 in ref. 10 and then converted to the $E_{\mathrm{s}}{ }^{\mathrm{c}}$ value according to Eq. 2 in ref. 9.

substitutent sufficiently. Each BP has a symmetrical "cage" structure, the two ends of which are greatly different in nature. One end is a polar phosphoryl group and the opposite one is a relatively hydrophobic bridgehead. Thus, BPs seem to enter deeply into the $\beta$-CD cavity from the side of the bridgehead, so that they can associate with $\beta$-CD more strongly than with $\alpha$ CD.

On the other hand, the structure-toxicity relationship for BPs was reexamined with the omission of ambiguous parameters from the data of Eto et al. ${ }^{4)}$ and Fujita ${ }^{12)}$ to give Eq. 5:

$$
\begin{aligned}
& \log 1 / \mathrm{LD}_{50}=5.235 \pi-1.556 \pi^{2} \\
&( \pm 0.599)( \pm 0.154)
\end{aligned}
$$

$$
\begin{gathered}
-0.704 E_{\mathrm{s}}^{\mathrm{c}}+1.494 \sigma^{*}-4.225, \\
( \pm 0.089) \quad( \pm 0.238) \\
n=14, \quad r=0.996, \quad s=0.091, \quad F=284.42,
\end{gathered}
$$

where $L D_{50}$ represents the median lethal dose for mice $(\mathrm{mg} / \mathrm{kg})$. (The $\pi$ values were evaluated from the hydrophobic fragmental constants.) Taking into account the fact that the $\pi^{2}$ term in this equation is regarded as a term concerned with the passive penetration of drugs to the sites of action, ${ }^{13)}$ there is a similarity between Eqs. 4 and 5 with regard to hydrophobic and steric parameters. This finding indicates that $\beta-C D$ is a good, though imperfect, model of the $\mathrm{BP}$ receptor. If the inside diameter of the receptor is smaller than that of $\beta$-CD, i.e., if it resembles that of $\alpha$ $\mathrm{CD}$, the sign of the $E_{\mathrm{s}}^{\mathrm{c}}$ term in Eq. 5 should be positive. On the contrary, if the inside of the receptor is much larger than the $\beta$-CD cavity, the $E_{\mathrm{s}}^{\mathrm{c}}$ term may not contribute to the regression equation for lack of van der Waals interaction. Thus, it seems reasonable to suppose that the BP receptor is a pore-type receptor, the inside diameter of which is similar to that of $\beta-C D(\sim 7.0 \AA)$. Toxic BPs may fit into the pore-type receptor in such a way as to block its normal physiological function.

Acknowledgments. The authors with to express their thanks to Professor Toshio Fujita for his valuable suggestion and to Professor Yoshihisa Matsui for his useful discussion. Thanks are also due to Messrs. Toshiyuki Kine and Shigeru Nakaya for their technical assistance. The present work was partially supported by a Grant-in-Aid for Scientific Research from the Ministry of Education, Science and Culture of Japan.

\section{REFERENCES}

1) E. M. Bellet and J. E. Casida, Science, 182, 1135 (1973).

2) N. G. Bowery, J. F. Collins and R. G. Hill, Nature, 261, 601 (1976).

3) S. Korenaga, Y. Ito, Y. Ozoe and M. Eto, Comp. Biochem. Physiol., 57C, 95 (1977).

4) M. Eto, Y. Ozoe, T. Fujita and J. E. Casida, Agric. Biol. Chem., 40, 2113 (1976)

5) D. W. Griffiths and M. L. Bender, Adv. Catal., 23, 209 (1973).

6) Y. Matsui and K. Mochida, Bull. Chem. Soc. Jpn., 52, 2808 (1979).

7) A. Leo, P. Y. C. Jow, C. Silipo and C. Hansch, $J$. Med. Chem., 18, 865 (1975).

8) C. Hansch and A. Leo, "Substituent Constants for Correlation Analysis in Chemistry and Biology," Wiley-Interscience, New York, N. Y., 1979, p. 52.

9) C. K. Hancock, E. A. Meyers and B. J. Yager, J. Am. Chem. Soc., 83, 4211 (1961).

10) T. Fujita, C. Takayama and M. Nakajima, J. Org. Chem., 38, 1623 (1973).

11) R. W. Taft, Jr., "Steric Effects in Organic 
Chemistry," ed. by M. S. Newman, John Wiley and Sons, Inc., New York, N. Y., 1956, p. 556.

12) T. Fujita, "Pesticide Design," ed. by I. Yamamoto and J. Fukami, Soft Science, Inc., Tokyo, 1979, p. 845 (in Japanese).
13) J. T. Penniston, L. Beckett, D. L. Bentley and C. Hansch, Mol. Pharmacol., 5, 333 (1969).

14) C. G. Evans and J. D. R. Thomas, J. Chem. Soc. B, 1971, 1502. 